\title{
Coral diversity and disease in Mexico
}

\author{
J. R. Ward ${ }^{1, *}$, K. L. Rypien ${ }^{1}$, J. F. Bruno ${ }^{2}$, C. D. Harvell ${ }^{1}$, E. Jordán-Dahlgren ${ }^{3}$, \\ K. M. Mullen ${ }^{4}$, R. E. Rodríguez-Martínez ${ }^{3}$, J. Sánchez ${ }^{5}$, G. Smith ${ }^{6}$ \\ ${ }^{1}$ Department of Ecology and Evolutionary Biology, Corson Hall, Cornell University, Ithaca, New York 14853, USA \\ ${ }^{2}$ Department of Marine Sciences, The University of North Carolina at Chapel Hill, Chapel Hill, North Carolina 27599-3300, USA \\ ${ }^{3}$ Instituto de Ciencias del Mar y Limnología, Universidad Nacional Autónoma de México, Apdo. Postal 1152, Cancún, 77500, \\ Quintana Roo, Mexico \\ ${ }^{4}$ Department of Entomology, Comstock Hall, Cornell University, Ithaca, New York 14853, USA \\ ${ }^{5}$ Departamento de Ciencias Biológicas, Universidad de los Andes, Carrera 1E No 18A-10, Bogotá, Colombia \\ ${ }^{6}$ Department of Biology and Geology, 471 University Parkway, Aiken, South Carolina 29801, USA
}

\begin{abstract}
Field studies and empirical tests of the 'diversity-disease hypothesis' demonstrate the effects of species richness on disease transmission and severity in plant systems. Yet the converse, i.e. effects of disease on diversity, is rarely considered in either relatively well-studied plant systems or marine ecosystems. We investigated these effects along the Mexican Yucatan Peninsula to (1) quantify the relationship between disease prevalence and coral diversity, (2) test the hypothesis that octocoral and scleractinian disease prevalence are associated with one another, and (3) establish a longterm dataset. Aspergillosis of sea fans and 6 scleractinian diseases were documented. Prevalence of aspergillosis declined from $12.85 \%$ in 2002 to $5.26 \%$ in 2004, while prevalence of scleractinian diseases remained relatively constant at $5.7 \pm 0.8 \%$ in 2002 and $7.96 \pm 0.7 \%$ in 2004 . Sites were relatively rich $(71$ species of octocoral and scleractinian corals) and even $(E 5>0.5)$. Sea fan disease prevalence was not associated with scleractinian disease prevalence, nor were there consistent associations between disease and measures of diversity. However, the most abundant octocoral and scleractinian species are susceptible to infection with several diseases, and disease may alter coral diversity in complex ways. These data represent the first in what will become a long-term dataset monitoring disease prevalence and associated changes in coral diversity.
\end{abstract}

KEY WORDS: Octocoral $\cdot$ Scleractinian $\cdot$ Disease $\cdot$ Diversity $\cdot$ Caribbean $\cdot$ Mexico $\cdot$ Richness $\cdot$ Evenness Resale or republication not permitted without written consent of the publisher

\section{INTRODUCTION}

Disease, whether caused by environmental stress, macroparasites, or pathogenic microorganisms, is a natural component of ecosystems. It can be a destructive force causing mortality, reduced fecundity, and reduced growth, or can have positive effects through maintenance of species richness and enhancement of host population genetic diversity and structure (Gilbert 2002). Disease can also pose a threat to biodiversity, particularly in fragmented or highly impacted areas (Hess 1996, McCallum \& Dobson 2002). Community biodiversity can be measured as the number of species (i.e. richness), relative abundance of species (i.e. even- ness), or a combination of richness and evenness (e.g. Shannon-Wiener Index). We investigated diversity (calculating richness and evenness separately) and disease in a Caribbean coral reef community.

Environmental variables, in particular temperature and nutrients, can affect disease prevalence and rate of spread on coral colonies. Several diseases of scleractinian corals, including black band disease, plague, and dark spots disease, as well as sea fan aspergillosis, are associated with warm water temperature (Alker et al. 2001, Kuta \& Richardson 2002). Experimental nutrient enrichment around sea fans (Gorgonia ventalina) and Montastraea annularis increases the rate of spread of aspergillosis and yellow band disease, respectively 
(Bruno et al. 2003). Thus, diseases affecting octocorals and scleractinians, though likely caused by different pathogens, are affected similarly by environmental variables.

Increases in coral disease, both non-infectious bleaching and infectious disease, pose a rising threat to coral reefs (Harvell et al. 2004, Ward \& Lafferty 2004). Yet the impacts of disease on reef ecosystems are poorly understood. In some cases, major shifts in community structure occur. For example, the shift from acroporid- to agaricid-dominated reefs in Belize was precipitated by disease-induced mortality of acroporid corals (Aronson et al. 2002). This is an example of a dramatic impact of disease on a community. The influence of less dramatic disease-related mortality on reef communities, in terms of richness, evenness and composition, is unclear.

The relationship between richness, evenness, and disease is complex and depends on community composition, host population dynamics and competitive interactions, pathogen identity, virulence and transmission, and the abiotic environment. Plant systems are relatively well studied with respect to these, and other factors, and may serve as a model for coral disease systems. Experimental tests of the effects of plant species richness on disease found that plots with low plant richness had higher host species abundance and increased disease transmission and severity relative to high richness plots (Mitchell et al. 2002). Field studies investigating the type of pathogen (host-specialist versus host-generalist) in sites with high and low species richness found that dispersal-limited, host specialized pathogens dominate low richness forests where host density is relatively high (Gilbert \& Sousa 2002). High richness forests favor host-generalist pathogens since the relative density of any one species is lower than that in low richness areas (Gilbert et al. 2002). These experimental and field studies in plant disease systems investigate the 'diversity-disease hypothesis' (sensu Mitchell et al. 2002), or the effects of diversity (in this case, richness) on disease severity and transmission.

The converse of the diversity-disease hypothesis, the 'disease-diversity hypothesis,' asks how disease affects species richness and evenness, and has not been empirically tested. However, several predictions can be made regarding the effects of disease on species richness and evenness. Disease will not alter richness unless (1) a particularly virulent pathogen causes $100 \%$ host mortality at a site, (2) rare species experience mortality, or (3) disease-induced mortality allows recruitment of less competitive species, thereby increasing richness. Disease will more likely impact evenness and community composition. Whether a site becomes more or less even depends on initial condi- tions, level of host mortality, pathogen host range, and response of non-host species to host mortality.

Because corals are not amenable to experiments in which diversity and disease are manipulated (e.g. as with plants; Knops et al. 1999, Mitchell et al. 2002), long-term in situ field studies provide an alternative to experimental manipulation. The Mexican Yucatan Peninsula is an ideal location to study disease dynamics on reefs because of relatively high scleractinian and octocoral richness, presence of disease, and planned development of coastal areas that could increase disease prevalence and severity. In addition, sea fans Gorgonia ventalina and G. mariae are abundant and signs of sea fan disease are relatively easy to survey, allowing a convenient test for associations between scleractinian and sea fan disease prevalence.

Permanent transects were established at 10 sites along the Mexican Yucatan Peninsula in 2002 to (1) quantify the relationship between disease prevalence and coral diversity, (2) test the hypothesis that octocoral and scleractinian disease prevalence are associated, and (3) establish a long-term dataset. The longterm (10 to $15 \mathrm{yr}$ ) goal of this project is to document the community level impacts of disease on coral reef ecosystems. Here we report results from the first $3 \mathrm{yr}$ of study and discuss potential changes in reef diversity and composition that may occur.

\section{MATERIALS AND METHODS}

Permanent transects were established at 10 haphazardly selected sites in Akumal, Mexico. Three parallel $25 \times 2 \mathrm{~m}$ transects were deployed, $10 \mathrm{~m}$ apart, at each site. Divers used SCUBA to record species of every octocoral and scleractinian coral within $1 \mathrm{~m}$ to either side of each transect and noted signs of disease, bleaching, and injury. More than 16000 octocoral and scleractinian coral colonies were surveyed each year. Spatial distribution of colonies along transects was noted by recording in which $5 \mathrm{~m}$ transect segment colonies were located. These data were used to make species accumulation curves. All curves plateau before $150 \mathrm{~m}^{2}$, indicating this is sufficient area to encompass diversity. Sea fan height was measured to the nearest $\mathrm{cm}$, and severity (percent of an infected colony with disease signs) was estimated. Sclerites were used to confirm in situ octocoral identifications (Bayer 1961). Sites were surveyed for all corals in 2002 and 2004, while only octocorals were surveyed in 2003.

Sea fan aspergillosis was identified by the presence of lesions (necrotic tissue, fouled skeleton, or exposed skeleton surrounded by dark purple tissue), tumors (thickened purple tissue and skeleton), or purpling (areas of dark purple tissue larger than $1 \mathrm{~cm}^{2}$, often asso- 
ciated with thickened axis) and absence of biotic factors that cause purpling (Millepora sp., contact with other octocorals or sponges, Cyphoma predation, hydroids). Aspergillosis was identified in sea fans only, because signs of infection in other octocorals are not reliable.

Black band disease was identified as a black mat several $\mathrm{mm}$ to $\mathrm{cm}$ wide on the surface of coral tissue. Healthy areas retained normal color and morphology. Signs of yellow band/blotch included irregularly shaped areas of lightened yellow tissue on the coral surface in early stage infections. Later stages had dead areas, sometimes filled with sediment or algae, surrounded by a band of yellow tissue (Cervino et al. 2001). White band disease usually started at the base of a branch with tissue detaching from the skeleton at a relatively uniform rate (Gladfelter 1982). Signs of white pox included necrotic patches, with necrosis at the boundary of the living coral tissue leaving behind a bare but otherwise undamaged skeleton. These necrotic patches were often colonized by filamentous algae or a thin layer of sediment, with the skeleton showing signs of degradation (Rodriguez-Martinez et al. 2001). White plague created a sharp line between receding tissue and skeleton (Bruckner \& Bruckner 1997, Richardson et al. 1998). Dark spot was identified as dark purple to gray or brown patches of discolored tissue, often circular in shape but also occurring in irregular shapes and patterns, scattered on the colony or adjacent to the sediment/algal margin of a colony (Garzon-Ferreira et al. 2001).

Total (no. diseased/no. colonies present) and hostspecific (no. colonies with a particular disease/no. host colonies present) disease prevalences were calculated for all scleractinians and octocorals. In addition, sea fan disease severity, the percent of an infected colony affected by aspergillosis, was calculated for all infected sea fans. Each prevalence and severity measure was calculated on 3 replicate transects per site. Transects with no host colonies for a particular disease were excluded from analyses of that disease's prevalence. Species richness (number of species) and evenness (relative abundance) were calculated using the entire $150 \mathrm{~m}^{2}$ at each site to encompass octocoral and scleractinian diversity.

Rather than combine richness and evenness measurements in one index, such as the Shannon-Wiener Diversity Index $\left(H^{\prime}\right)$, the association of these measurements with disease prevalence and severity was tested separately. The most common evenness index used is

$$
E 1=\frac{H^{\prime}}{\ln (S)} \text { where } H^{\prime}=-\sum p_{i}\left(\log _{\mathrm{e}} p_{i}\right)
$$

where $p_{i}$ is the proportion of individuals in species $i$, and $S$ is the number of species. However, addition of a single rare species greatly changes the value of $E 1$
(Ludwig \& Reynolds 1988). E5, another measure of evenness, is less affected by rare species and approaches zero as a single species becomes dominant in the community, a convenient property for a measure of evenness (Alatalo 1981, Ludwig \& Reynolds 1988).

$$
E 5=\frac{\frac{1}{\lambda}-1}{\mathrm{e}^{H^{\prime}}-1} \text { where } \lambda=\sum \frac{n^{2}}{N^{2}}=\sum p_{i}{ }^{2}
$$

where $n$ is the number of individuals in a species, $N=$ $\sum n$, and $p_{i}$ is as above (Alatalo 1981).

Disease prevalence is higher among sea fans in larger size classes (Nagelkerken et al. 1997a, Kim \& Harvell 2002), and addition of new recruits can drastically lower prevalence estimates even if total number of infections remains constant through time. Thus, prevalence was calculated both among all fans and among only those larger than $10 \mathrm{~cm}$.

Data are presented as means $(\bar{X}) \pm$ standard error (SE). Assumptions of normality (Shapiro-Wilks) and homogeneity of variance (Levene's test of homogeneity) were tested prior to analysis. Data that were not normally distributed were homoscedastic, except sea fan disease prevalence. Because the Levene's test of homogeneity is conservative, the sea fan disease prevalence residual plot was acceptable, and since ANOVA is robust with respect to violations of the normality assumption, untransformed data were used in all analyses. Prevalence and severity data were analyzed using 3 replicate measurements per site. Richness and evenness analyses used one richness or evenness value and a mean prevalence and severity for each site. Repeated measures ANOVA was used to test for changes in prevalence and severity among sites and through time. Associations between diversity and disease measurements, and associations with depth were tested with Pearson product-moment correlation (SAS v8.0, copyright SAS). Holm's sequential Bonferroni adjustments were used to control for multiple comparisons (Holm 1979).

\section{RESULTS}

In all years, disease prevalence in large $(>10 \mathrm{~cm})$ sea fans was higher than prevalence calculated among all sea fans (Fig. 1). Substituting prevalence in large fans for prevalence among all fans did not alter significance of results in any analysis; thus, the results reported here used prevalence calculated from all sea fans.

We identified 31 octocoral species with maximum site richness of 28 and evenness ranging from $E 5=0.43$ to 0.73 (Fig. 2A). Pseudopterogorgia americana and Gorgonia ventalina were the most abundant octocorals comprising $35.3 \%$ of the octocoral community (Fig. 3). Sea fan aspergillosis prevalence decreased from 12.85 


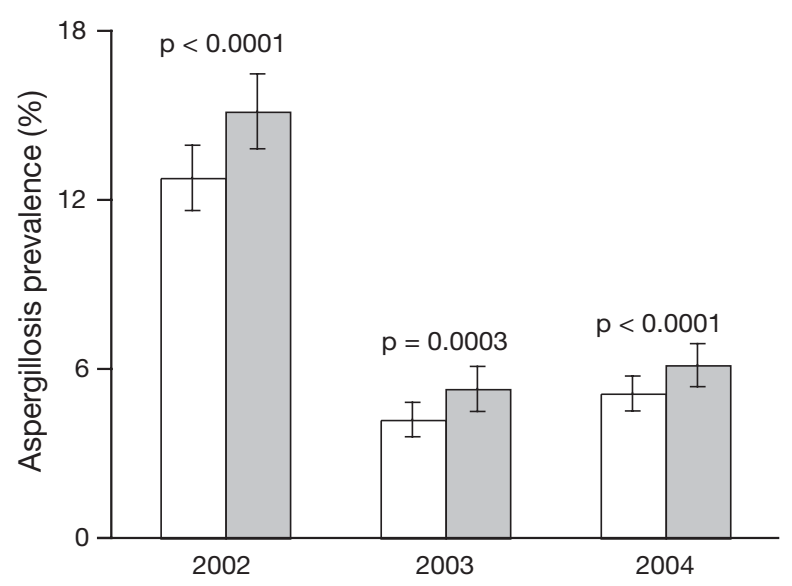

Fig. 1. Gorgonia ventalina and G. mariae. Prevalence of sea fan aspergillosis calculated from all fans (open bars) and only fans $>10 \mathrm{~cm}$ in height (filled bars) in each survey year. $\mathrm{p}$ values $=$ significance of paired $t$-tests. Error bars: SE

$\pm 1.17 \%$ in 2002 to $4.19 \pm 0.62 \%$ in 2003 , and remained low $(5.26 \pm 0.65 \%)$ in 2004 (Fig. 4A). Sea fan aspergillosis severity decreased from 2002 to 2003 and increased again by 2004 (Fig. 4A). Sea fan aspergillosis prevalence and severity were not associated in 2002 or 2003 but were positively associated in 2004 (Fig. 5).

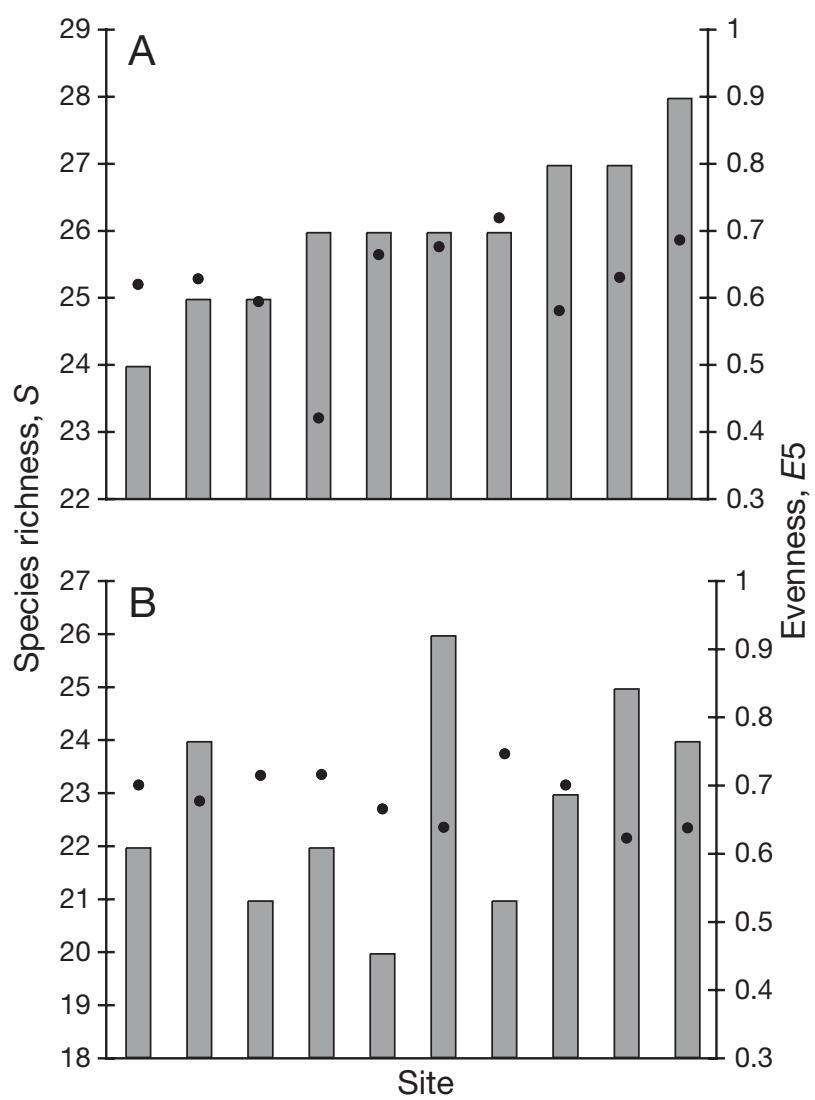

Fig. 2. Species richness (bars, left axis) and evenness (circles, right axis) of (A) octocorals and (B) scleractinians at each site
A total of 40 species of scleractinian coral were identified; maximum richness was 26, and sites were relatively even, with E5 ranging from 0.63 to 0.75 (Fig. 2B). Six scleractinian diseases infecting 19 species in 12 genera were documented (Table 1) with mean disease prevalence of $5.7 \pm 0.8 \%$ in 2002 and $7.96 \pm 0.7 \%$ in 2004 but no significant difference among sites or years (Fig. 4B). The most abundant scleractinian disease in 2002 was dark spot infecting up to $11.1 \%$ (mean: $4.3 \pm$ $0.9 \%$ ) of scleractinian colonies at a site. In 2004, dark spot affected $2.9 \pm 0.6 \%$ of corals, while yellow band was the most prevalent disease affecting $0.9 \%$ of colonies.

Siderastrea siderea, Agaricia agaricites, and Montastraea annularis, the most abundant scleractinian species, comprised $42 \%$ (2002) and $49.8 \%$ (2004) of the scleractinian community (Fig. 6A). Each of these abundant scleractinian species is susceptible to multiple disease, although not all diseases were documented at the sites (Table 1). The most abundant scleractinian genera were Porites, Montastraea, Siderastrea, and Agaricia comprising 86.6\% of colonies (Fig. 6B). Montastraea sp. had the highest disease prevalence (27 \pm $3.8 \% 2004$ ) of any scleractinian genus (Fig. 6B).

Neither sea fan disease prevalence nor severity correlated with scleractinian disease prevalence (Table 2). Octocoral and scleractinian richness and evenness

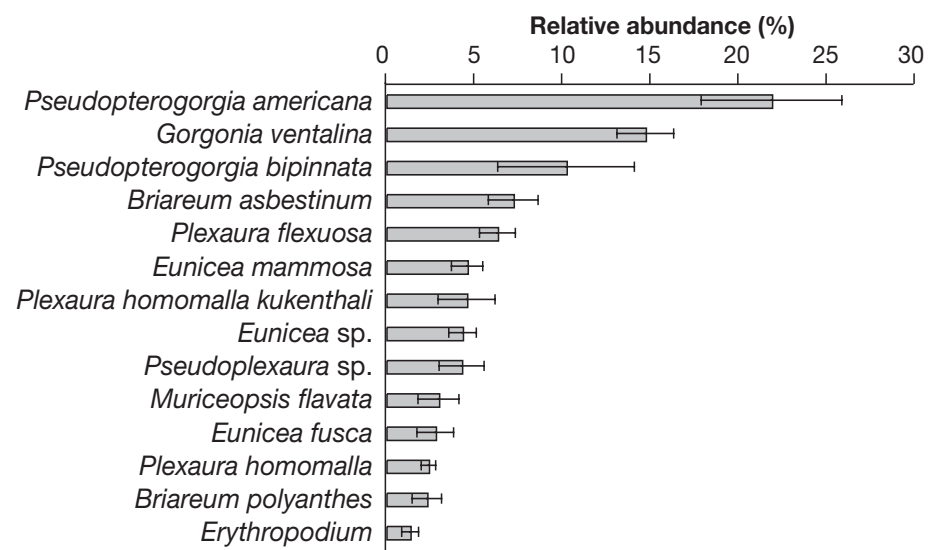

Pseudoplexaura crucis 마

Pseudopterogorgia acerosa 바 Gorgonia mariae 마 Plexaurella fusifera $\square$ Eunicea tourneforti $⿴ 囗 十$ Plexuara kuna Eunicea laciniata $\mathrm{BH}$

Eunicea columbiana $\mathbb{B}$ Eunicea succinea $\mathbb{E}$ Plexaurella grisea 0 Muricea atlantica $\theta$ Plexaurella dichotoma $\mathbb{\text { ⿴囗十 }}$ Plexaurella obesa 1 Pterogorgia citrina Pterogorgia anceps Plexaurella nutans Eunicea calyculata
Fig. 3. Relative abundance of octocoral species among all sites, 2004. Error bars: SE 


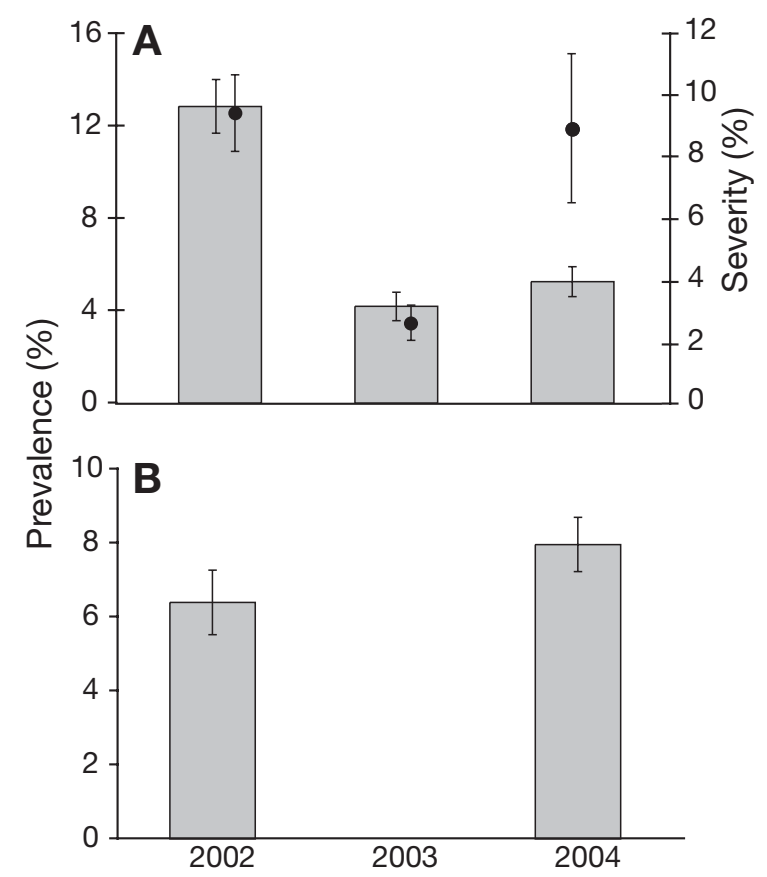

Fig. 4. (A) Prevalence (bars, left axis) and severity (circles, right axis) of sea fan aspergillosis. Repeated measures ANOVA revealed an effect of time $(p<0.0001 ; 2002$ different from other years) but no effect of site $(p=0.29)$ or time $\times$ site $(p=0.59)$ on prevalence. Severity changed with time $(p=$ $0.003 ; 2003$ different from other years) but there was no effect of site $(p=0.5559)$ or time $\times$ site $(p=0.8943)$ (repeated measures ANOVA). (B) Prevalence of scleractinian disease in 2002 and 2004. Neither time $(p=0.23)$, site $(p=0.46)$, nor time $\times$ site $(p=0.20)$ were significant (repeated measures ANOVA). Error bars: SE

were not associated with sea fan disease or scleractinian disease prevalence (Table 2). In 2002, octocoral richness predicted sea fan disease severity, but the trend did not hold in 2003 or 2004 (Fig. 7). There were no trends with octocoral evenness (Table 2).

Only octocoral richness in 2004, scleractinian richness in 2004, and scleractinian disease prevalence in 2002 were associated with depth (increase in richness with depth, decrease in prevalence with depth; Table 2); however the trends are not significant when using sequential Bonferroni adjustments. There was no association with depth for any other richness, evenness, disease prevalence or severity measurement (Table 2).

\section{DISCUSSION}

Corals face multiple stressors, both natural (e.g. storms, herbivory) and anthropogenic (e.g. increased sedimentation, nutrification). Diseases caused by pathogenic microorganisms can be exacerbated by anthropogenic activities such as eutrophication (Bruno et al. 2003). Given the intractable nature of experimen-
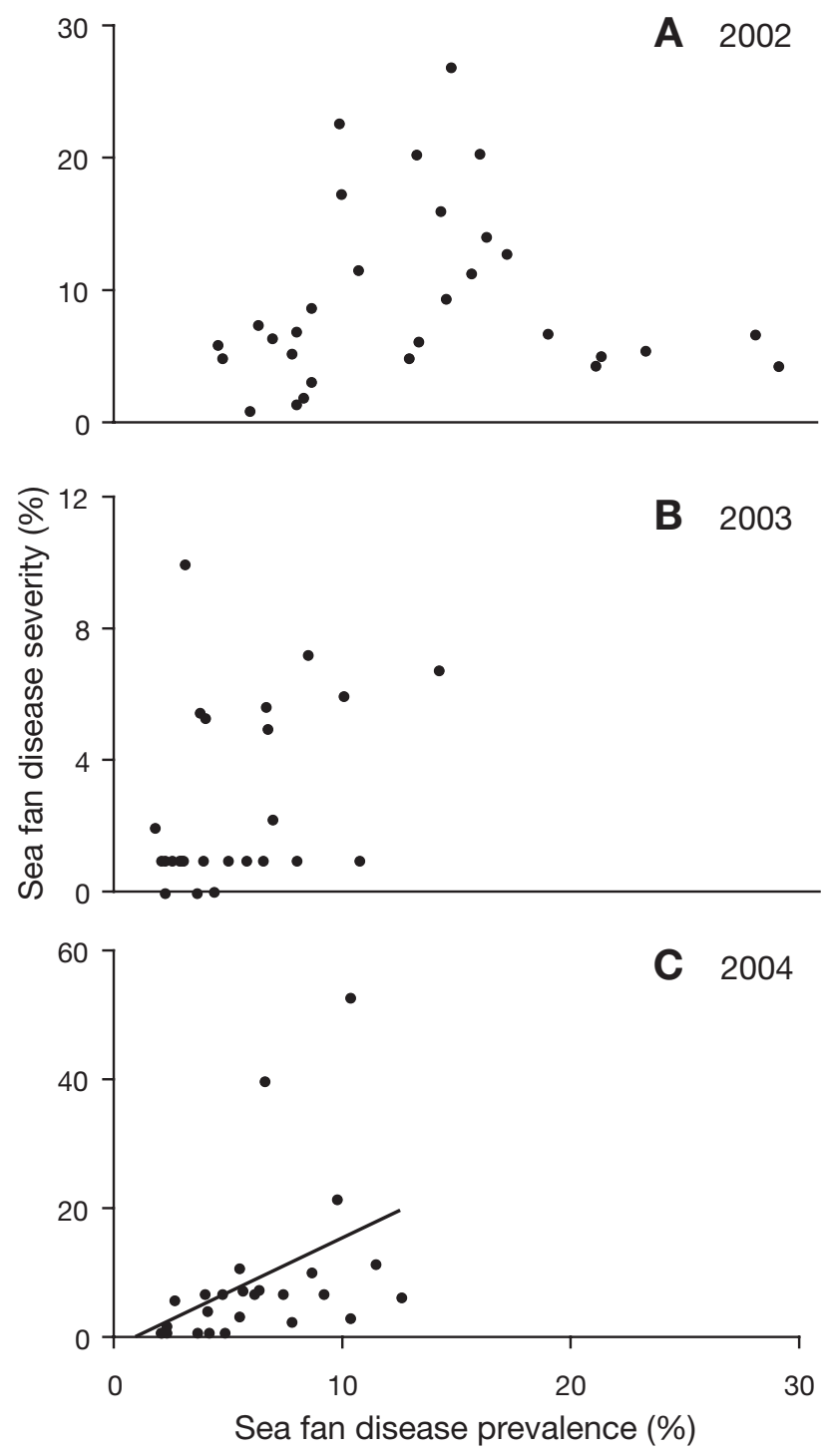

Fig. 5. Gorgonia ventalina and G. mariae. Sea fan disease prevalence and severity in 2002, 2003, and 2004. There were no significant associations in $2002\left(p=0.74, R^{2}=0.004\right)$ or 2003 $\left(p=0.06, R^{2}=0.146\right)$. Prevalence and severity were positively associated in 2004 (linear regression, $p=0.03, R^{2}=0.1855$ )

tally testing the effects of disease on coral diversity, we used comprehensive, quantitative in situ field surveys to assess coral richness, evenness, and disease at 10 sites along the Mexican Yucatan Peninsula.

The most abundant octocorals, Pseudopterogorgia americana and Gorgonia ventalina (Fig. 3), are susceptible to infection with the pathogenic fungus Aspergillus sydowii (Geiser et al. 1998, Weil et al. 2002, Smith \& Weil 2004). Siderastrea siderea, Agaricia agaricites, and Montastraea annularis, the most abundant scleractinians (Fig. 6A), are susceptible to several diseases (Table 1). If these abundant species experience high mortality either due to a virulent pathogen 
Table 1. Scleractinian corals and diseases. Numbers indicate species previously recorded as hosts: 1 = reviewed in Sutherland et al. (2004), 2 = G. Smith (pers. obs.). ${ }^{*}$ Disease found on at least 1 colony surveyed, $\mathrm{sp}=$ species could not be determined; $\mathrm{BBD}=$ black band disease, $\mathrm{DSD}=$ dark spots disease, $\mathrm{YB}=$ yellow $\mathrm{band} / \mathrm{blotch}$, Wpox $=$ white pox, Wband $=$ white band, $\mathrm{WPL}=$ white plague

\begin{tabular}{|c|c|c|c|c|c|c|}
\hline \multirow[t]{2}{*}{ Species } & \multicolumn{6}{|c|}{ Diseases } \\
\hline & $\mathrm{BBD}$ & DSD & YB & WPL & Wpox & Wband \\
\hline Acropora cervicornis & & & & & & $1^{*}$ \\
\hline Acropora palmata & 1 & & & & $1^{*}$ & 1 \\
\hline Acropora prolifera & & & & & & \\
\hline Agaricia agaricites & & $1^{*}$ & 1 & 1 & & \\
\hline Agaricia fragilis & & & & 1 & & \\
\hline Agaricia humilis & & & & & & \\
\hline Agaricia lamarcki & & & & 1 & & \\
\hline Agaricia tenufolia & & & & 1 & & \\
\hline Agaricia undata & & & & & & \\
\hline Colpophyllia natans & 1 & 1 & 1 & 1 & & \\
\hline Dendrogyra cylindrus & $2^{*}$ & & & 1 & & \\
\hline Dichocoenia stokesi & 1 & & & $1^{*}$ & & \\
\hline Diploria clivosa & 1 & & & 1 & & \\
\hline Diploria labyrinthiformis & 1 & 1 & $1^{*}$ & 1 & & \\
\hline Diploria strigosa & $1^{*}$ & $2^{*}$ & 1 & 1 & & \\
\hline Eusmilia fastigiata & & & & 1 & & \\
\hline Helioseris cuculata & & & & & & \\
\hline Isophyllia sinuosa & & & & 1 & & \\
\hline Isophyllastrea rigida & & 1 & & 1 & & \\
\hline Madracis decactis & 1 & & & 1 & & \\
\hline Madracis mirabilis & & & & & & \\
\hline Meandrina meandrites & $1^{*}$ & 1 & * & 1 & & \\
\hline Montastraea annularis & 1 & $1^{*}$ & 1 & $1^{*}$ & & \\
\hline Montastraea cavernosa & 1 & $1^{*}$ & $2^{*}$ & 1 & & \\
\hline Montastraea faveolata & 1 & $1^{*}$ & $1^{*}$ & $1^{*}$ & & \\
\hline Montastraea franksi & 1 & $1^{*}$ & $1^{*}$ & $1^{*}$ & & \\
\hline Mycetophyllia aliciae & & & & 1 & & \\
\hline Mycetophyllia danaana & $2^{*}$ & & & 1 & & \\
\hline Mycetophyllia ferox & & & & 1 & & \\
\hline Mycetophyllia lamarkiana & & & & 1 & & \\
\hline Oculina robusta & & & ${ }^{*}$ & & & \\
\hline Porites astreoides & $1^{*}$ & & 1 & 1 & & \\
\hline Porites 'branneri' & & & & & & \\
\hline Porites divericata & & & & & & \\
\hline Porites furcata & & & & & & \\
\hline Porites porites & $2^{*}$ & & & $1^{*}$ & & \\
\hline Scolymia sp. & & & & & & \\
\hline Siderastrea radians & 1 & $*$ & & 1 & & \\
\hline Siderastrea siderea & 1 & $1^{*}$ & & $1^{*}$ & & \\
\hline Solenastrea bournoni & & & & 1 & & \\
\hline Stephanocoenia interseptá & $\begin{array}{l}a \\
a\end{array}$ & $1^{*}$ & & 1 & & \\
\hline
\end{tabular}

strain or to abiotic environmental factors that increase prevalence or severity of current strains, coral community structure and composition could change drastically. In addition, local extinction of rare coral species is possible if host-generalist pathogens 'spill-over' from abundant to rare species (Cleaveland et al. 2003). Spill-over is particularly important in areas predicted to be dominated by host-generalists, such as reefs along the Yucatan (Gilbert 2002).

Sea fan aspergillosis, currently present at low levels (Fig. 4), could increase with predicted increases in sea surface temperature (Houghton et al. 2001) and addition of nutrients (Bruno et al. 2003) associated with coastal development. Prevalence and severity of aspergillosis were not associated in 2002 or 2003 (Fig. 5A,B) nor did they predict the occurrence of other diseases along the Yucatan Peninsula during the study period (Table 2). One trend, the inverse association between disease severity and octocoral richness in 2002 (Fig. 7A), was predicted and experimentally tested in plant systems. Relatively high richness sites are predicted to have lower disease transmission and severity because hosts are less abundant than in low richness sites. The trend was not detected in 2003 or 2004, probably due to the decline in prevalence of aspergillosis (Fig. 7B,C).

Other factors, such as depth, can influence disease dynamics. Previous studies found an association of depth and aspergillosis prevalence (Nagelkerken et al. 1997a, K. M. Mullen unpubl.). However, neither sea fan disease prevalence nor severity varied with depth in this study. We did detect an increase in scleractinian disease prevalence with depth in 2002, but not in 2004 (Table 2), although associations of scleractinian disease and depth are not temporally or spatially consistent. For example, Croquer et al. (Croquer et al. 2003) reported increased prevalence of white plague type II disease at deep (>9 m) sites in Venezuela, while Borger (2003) reported no effect of depth on black band, white plague, or dark spots disease in Dominica.

Table 2. Correlation analyses testing for associations between number of colonies, richness, evenness, disease prevalence, disease severity, and depth. ${ }^{*}$ Significance at $p=0.05$. No correlations are significant using sequential Bonferroni adjustments

\begin{tabular}{|c|c|c|}
\hline $\begin{array}{c}\text { Variable } \\
\text { versus }\end{array}$ & $\mathrm{r}$ & Year \\
\hline \multicolumn{3}{|l|}{ Number of scleractinian colonies } \\
\hline Scleractinian richness & 0.01 & 2004 \\
\hline Scleractinian evenness & 0.41 & 2004 \\
\hline \multicolumn{3}{|l|}{ Number of octocoral colonies } \\
\hline Octocoral richness & $0.21 / 0.18 / 0.53$ & 2002/2003/2004 \\
\hline Octocoral evenness & $0.41 / 0.39 / 0.64$ & $2002 / 2003 / 2004$ \\
\hline \multicolumn{3}{|l|}{ Sea fan disease prevalence } \\
\hline Scleractinian disease prevalence & $0.31 / 0.14$ & $2002 / 2004$ \\
\hline Octocoral richness & $0.05 / 0.14 / 0.43$ & 2002/2003/2004 \\
\hline Octocoral evenness & $0.12 / 0.58 / 0.46$ & $2002 / 2003 / 2004$ \\
\hline \multicolumn{3}{|l|}{ Sea fan disease severity } \\
\hline Scleractinian disease prevalence & $0.1 / 0.07$ & $2002 / 2004$ \\
\hline Octocoral richness & $0.79 * / 0.04 / 0.17$ & 2002/2003/2004 \\
\hline Octocoral evenness & $0.21 / 0.25 / 0.18$ & 2002/2003/2004 \\
\hline \multicolumn{3}{|l|}{ Scleractinian disease prevalence } \\
\hline Scleractinian richness & 0.23 & 2004 \\
\hline Scleractinian evenness & 0.11 & 2004 \\
\hline \multicolumn{3}{|l|}{ Depth } \\
\hline Scleractinian richness & $0.10 / 0.39$ & $2002 / 2004$ \\
\hline Scleractinian evenness & $0.42 / 0.54$ & $2002 / 2004$ \\
\hline Scleractinian disease prevalence & $0.45 * / 0.02$ & $2002 / 2004$ \\
\hline Octocoral richness & $0.57 / 0.51 / 0.75^{*}$ & 2002/2003/2004 \\
\hline Octocoral evenness & $0.33 / 0.43 / 0.21$ & $2002 / 2003 / 2004$ \\
\hline Sea fan disease prevalence & $0.21 / 0.02 / 0.24$ & $2002 / 2003 / 2004$ \\
\hline Sea fan disease severity & $0.27 / 0.08 / 0.22$ & $2002 / 2003 / 2004$ \\
\hline
\end{tabular}



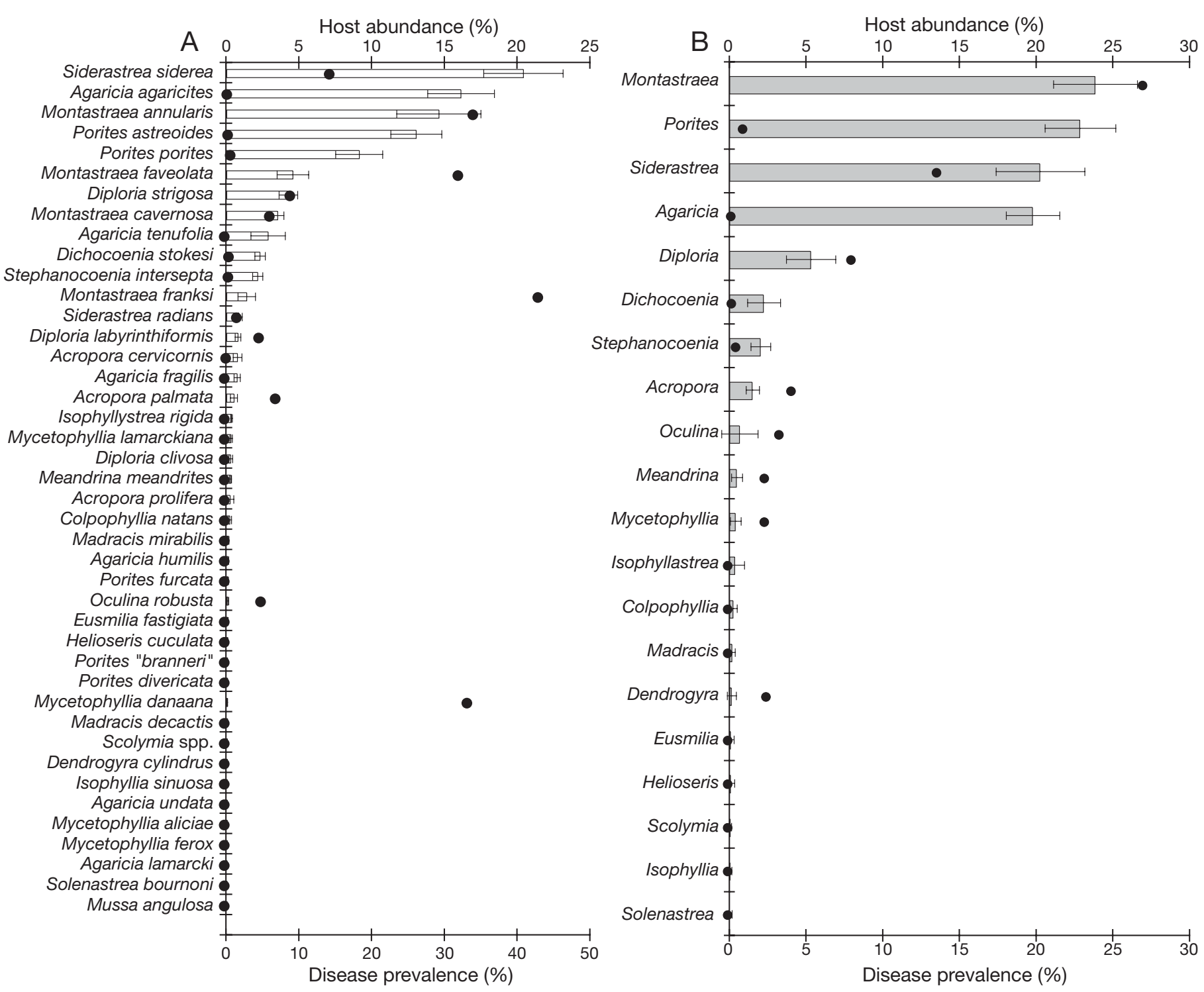

Fig. 6. Host abundance ( $\%$ of total colonies counted, bars, top axis) and disease prevalence (circles, bottom axis) of (A) scleractinian species and (B) scleractinian genera in 2004. Error bars: SE

A drawback of any study initiated post-disturbance is the lack of baseline, pre-disturbance data. This study is no exception, as aspergillosis was reported from this region in 1995 (Nagelkerken et al. 1997b) but richness and evenness data were not collected until 2002. At the height of the aspergillosis epizootic, mortality was 60 to $100 \%$ in some areas of the Caribbean (Nagelkerken et al. 1997a). Assuming similar levels of mortality along the Yucatan, octocoral communities may have been altered by disease prior to the start of this study. The same is true for scleractinians affected by disease prior to this study. This lack of baseline disease and diversity data for most marine organisms (Ward \& Lafferty 2004) emphasizes the need for long-term monitoring projects such as those initiated in the Florida Keys (Porter et al. 2001, Kim \& Harvell 2004).
Recovery from disease on Yucatan reefs could be hindered by increased nutrients associated with development and high sea surface temperatures predicted by climate change models (Houghton et al. 2001). Progression of yellow band disease on Montastraea is accelerated by experimentally elevated nutrient levels (Bruno et al. 2003), and black band disease is more active in warm $\left(>25^{\circ} \mathrm{C}\right.$ ) water (Rutzler et al. 1983). Sea fan aspergillosis is also exacerbated by elevated nutrients (Bruno et al. 2003) and temperature (Alker et al. 2001).

In addition, reproductive suppression of infected hosts (Petes et al. 2003) may alter population dynamics through reduced fecundity and subsequent recruitment limitation. Suppression of size or resilience of host populations may increase host vulnerability to extinction (Cleaveland et al. 2003). If disease continues 

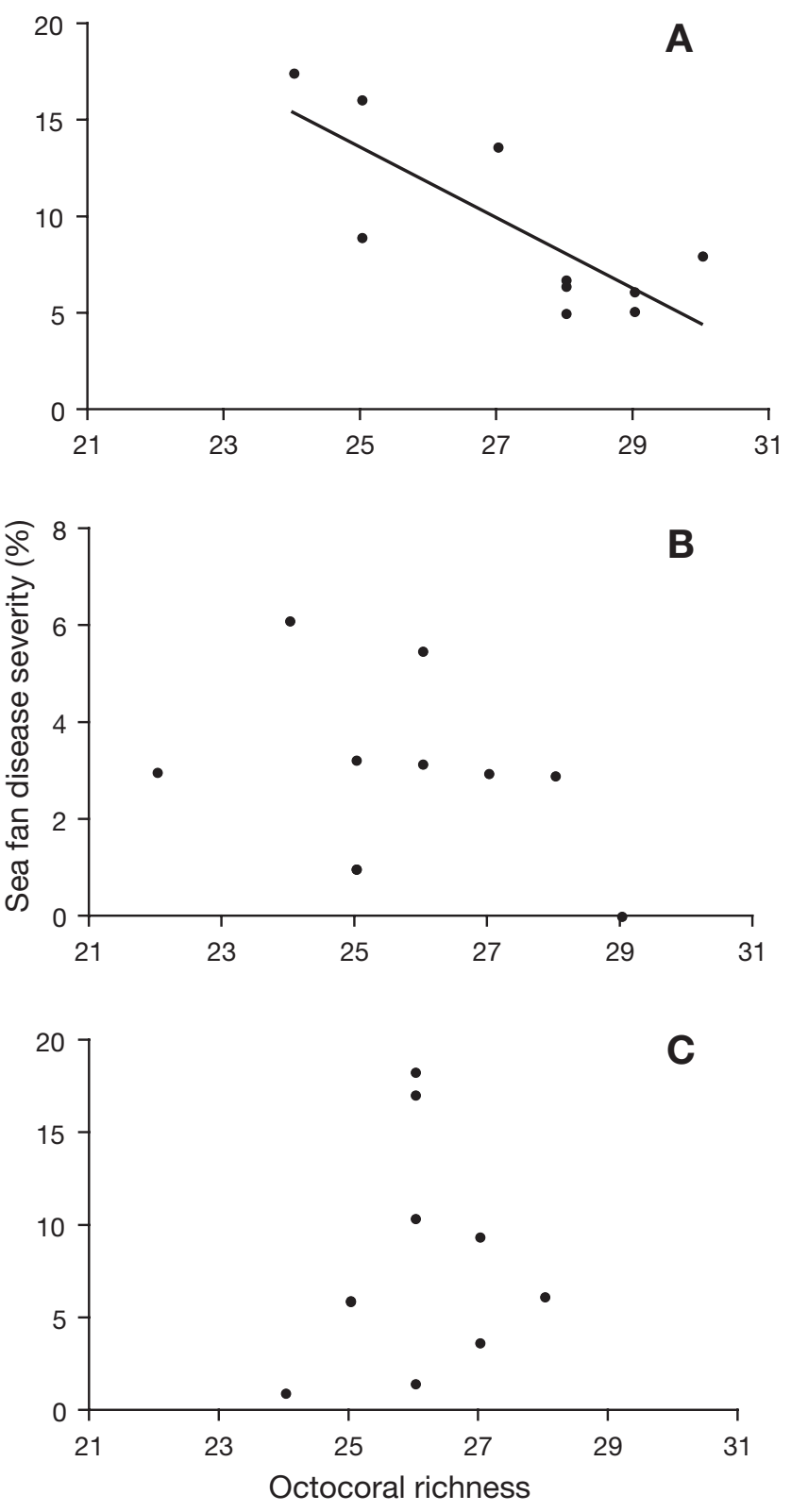

Fig. 7. Gorgonia ventalina and G. mariae. Sea fan disease severity as a function of octocoral richness in (A) 2002 ( $p=$ 0.01， $\left.\mathrm{R}^{2}=0.62\right)$ ，(B) $2003\left(\mathrm{p}=0.92, \mathrm{R}^{2}=0.001\right)$, (C) $2004(\mathrm{p}=$ $\left.0.64, R^{2}=0.03\right)$

to affect Yucatan reefs, areas with high levels of disease will likely show changes in evenness and richness. Loss of species may also alter ecosystem functioning and affect higher trophic levels (Knops et al. 1999).

Tools to predict and mitigate effects of disease in coral reefs, and marine ecosystems in general, are currently under-developed (Harvell et al. 2004). While plant systems provide a basis for predicting effects of diversity (richness) on disease (Gilbert 2002), the effects of disease on diversity (both richness and even- ness) are unclear. Until pathogenic microorganisms are identified, origins and reservoirs of disease discovered, and role of anthropogenic stressors understood, developing effective management strategies is difficult (Harvell et al. 2004). In the meantime, quantitative field studies, as reported here, provide an ecologically relevant assessment of disease dynamics that, over time, will reveal impacts of disease on coral communities.

Acknowledgements. This work was part of the World Bank/Global Environment Facility Coral Reef Targeted Research and Capacity Building program and was supported by an NSF Graduate Research Fellowship (J.R.W), NSERC Postgraduate Scholarship (K.L.R), NSF OCE 0326705 (C.D.H). We thank J. Andras, N. Douglas, J. Fox, N. Galliher, N. Hairston, A. Hettinger, K. Kim, B. Mahoney, M. Maldonado, L. Petes, S. Talmage, N. Tisch, and the Akumal Dive Shop for diving support, K. Robinhawk, C. Shaw and the Centro Ecológico Akumal for laboratory space, H. Atarie and L. Bush for housing. We thank the Harvell Lab, L. Jones, K. Kim, S. Ellner, and an anonymous reviewer for comments that improved the manuscript.

\section{LITERATURE CITED}

Alatalo RV (1981) Problems in the measurement of evenness in ecology. Oikos 37:199-204

Alker AP, Smith GW, Kim K (2001) Characterization of Aspergillus sydowii (Thom et Church), a fungal pathogen on Caribbean sea fan corals. Hydrobiologia 460:105-111

Aronson RB, Macintyre IG, Precht WF, Murdoch TJT, Wapnick CM (2002) The expanding scale of species turnover events on coral reefs in Belize. Ecol Monogr 72:233-249

Bayer FM (1961) The shallow water Octocorallia of the West Indian Region. Marinus Nijhoff, The Hague

Borger JL (2003) Three scleractinian coral diseases in Dominica, West Indies: distribution, infection patterns and contribution to coral tissue mortality. Rev Biol Trop 51 (Suppl 4): 25-38

Bruckner AW, Bruckner RJ (1997) Outbreak of coral disease in Puerto Rico. Coral Reefs 16:260

Bruno JF, Petes LE, Harvell CD, Hettinger A (2003) Nutrient enrichment can increase the severity of coral diseases. Ecol Lett 6:1056-1061

Cervino J, Goreau TJ, Nagelkerken I, Smith GW, Hayes R (2001) Yellow band and dark spot syndromes in Caribbean corals: distribution, rate of spread, cytology, and effects on abundance and division rate of zooxanthellae. Hydrobiologia 460:53-63

Cleaveland S, Hess GR, Dobson AP, Laurenson MK, McCallum HI, Roberts MG, Woodroffe R (2003) The role of pathogens in biological conservation. In: Hudson PJ, Rizzoli A, Grenfell BT, Heesterbeek H, Dobson AP (eds) The Ecology of Wildlife Diseases. Oxford University Press, Oxford, p 139-150

Croquer A, Pauls SM, Zubillaga AL (2003) White plague disease outbreak in a coral reef at Los Roques National Park, Venezuela. Rev Biol Trop 51 (Suppl 4):39-45

Garzon-Ferreira J, Gil-Agudelo DL, Barrios LM, Zea S (2001) Stony coral diseases observed in southwestern Caribbean reefs. Hydrobiologia 460:65-69

Geiser DM, Taylor WT, Ritchie KB, Smith GW (1998) Cause of sea fan death in the West Indies. Nature 394:137-138 
Gilbert GS (2002) Evolutionary ecology of plant diseases in natural ecosystems. Annu Rev Phytopathol 40:13-43

Gilbert GS, Sousa WP (2002) Host specialization among wooddecay polypore fungi in a Caribbean mangrove forest. Biotropica 34:396-404

Gilbert GS, Ferrer A, Carranza J (2002) Polypore fungal diversity and host density in a moist tropical forest. Biodivers Conserv 11:947-957

Gladfelter WB (1982) White-band disease in Acropora palmata: implications for the structure and growth of shallow reefs. Bull Mar Sci 32:639-643

Harvell D, Aronson RB, Baron N, Connell J and 13 others (2004) The rising tide of ocean diseases: unsolved problems and research priorities. Front Ecol Environ 2:375-382

Hess G (1996) Disease in metapopulation models: implications for conservation. Ecology 77:1617-1632

Holm S (1979) A simple sequentially rejective multiple test procedure. Scand J Stat 6:65-70

Houghton JT, Ding Y, Griggs DJ, Noguer M, van der Linden PJ (eds) (2001) Climate Change 2001: The Scientific Basis, Intergovernmental Panel on Climate Change. Cambridge University Press, Cambridge

Kim K, Harvell CD (2002) Aspergillosis of sea fan corals: disease dynamics in the Florida Keys, USA. In: Porter J, Porter K (eds) Linkages between ecosystems in the South Florida Hydroscapes. CRC, Boca Raton, FL, p 813-824

Kim K, Harvell CD (2004) The rise and fall of a six year coralfungal epizootic. Am Nat 164:S52-S63

Knops JMH, Tilman D, Haddad NM, Naeem S and 7 others (1999) Effects of plant species richness on invasion dynamics, disease outbreaks, insect abundances and diversity. Ecol Lett 2:286-293

Kuta KG, Richardson LL (2002) Ecological aspects of black band disease of corals: relationships between disease incidence and environmental factors. Coral Reefs 21:393-398

Ludwig JA, Reynolds JF (1988) Statistical ecology: a primer on methods and computing. Wiley, New York, p 85-106

McCallum H, Dobson A (2002) Disease, habitat fragmentaion and conservation. Proc R Soc Lond Biol Sci 269:2041-2049

Submitted: September 28, 2004; Accepted: May 20, 2005
Mitchell CE, Tilman D, Groth JV (2002) Effects of grassland plant species diversity, abundance, and composition on foliar fungal disease. Ecology 83:1713-1726

Nagelkerken I, Buchan K, Smith GW, Bonair K and 10 others (1997a) Widespread disease in Caribbean sea fans: II. Patterns of infection and tissue loss. Mar Ecol Prog Ser 160:255-263

Nagelkerken I, Buchan K, Smith GW, Bonair K and 8 others (1997b) Widespread disease in Caribbean sea fans: I. Spreading and general characteristics. Proc 8th Int Coral Reef Symp 1:679-682

Petes L, Harvell CD, Peters EC, Webb MAH, Mullen KM (2003) Pathogens compromise reproduction and induce melanization in Caribbean sea fans. Mar Ecol Prog Ser 264:167-171

Porter JW, Dustan P, Jaap WC, Patterson KL, Kosmynin V, Meier OW, Patterson ME, Parsons M (2001) Patterns of spread of coral disease in the Florida Keys. Hydrobiologia 460:1-24

Richardson LL, Goldberg WM, Kuta KG, Aronson RB and 5 others (1998) Florida's mystery coral-killer identified. Nature 392:557-558

Rodriguez-Martinez RE, Banaszak AT, Jordan-Dahlgren E (2001) Necrotic patches affect Acropora palmata (Scleractinia: Acroporidea) in the Mexican Caribbean. Dis Aquat Org 47:229-234

Rutzler K, Santavy DL, Antonius A (1983) The black band disease of Atlantic reef corals: III. Distribution, ecology, and development. PSZN I: Mar Ecol 4:329-358

Smith G, Weil E (2004) Aspergillosis of gorgonians. In: Rosenberg E, Loya Y (eds) Coral health and disease. Springer, Berlin, p 279-287

Ward JR, Lafferty KD (2004) The elusive baseline of marine disease: are diseases in ocean ecosystems increasing? PLoS Biol 2:542-547

Weil E, Urreiztieta I, Garzon-Ferreira J (2002) Geographic variability in the incidence of coral and octocoral diseases in the wider Caribbean. Proc 9th Int Coral Reef Symp, Bali 2:1231-1237

Proofs received from author(s): January 31, 2006 